\title{
IMPLEMENTASI CERITA KREATIF DENGAN MENGGUNAKAN METODE \\ PAIKEM UNTUK MENINGKATKAN AKTIVITAS BELAJAR ANAK SGM DI GEREJA TORAJA
}

\author{
Nama : Krstiani Timang \\ Nirm : 1020175382 \\ Kelas : C/PAK
}

\section{A. Abstrak}

Setiap Gereja memiliki tanggung jawab untuk membina dan membimbing warga Gerejanya. Terutama bagi anak SMG dimana warga gereja wajib mengenalkan anakanak kepada Yesus Sang Juruselamat. Salah satu cara untuk mengenalkan anak-anak kepada Yesus Kristus adalah dengan cara menyampaikan cerita yang kreatif dan dapat mengkontekstualkannya sesuai dengan batas usia anak agar muda di pahami dengan baik. Tujuan dari penelitian ini adalah untuk menemukan cara bercerita dengan kreatif dan kontekstual untuk meningkatkan aktivitas belajar anak SGM di Gereja Toraja. Metode cerita ini merupakan metode cerita yang kreatif atau biasa disebut dengan metode PAIKEM dan dapat mengkontekstualkan sesuai usia anak. ${ }^{1}$

Kata Kunci: Cerita Kreatif, Metode Paikem, Anak SGM

\section{B. Pendahuluan}

Gereja adalah orang-orang yang percaya kepada Yesus Kristus, gereja ada untuk memberikan kesaksian bagi kebenaran yang dari Allah. Kebenaran itu telah dinyatakanNya melalui kedatangaN Yesus Kristus ke dunia. Salah satu bentuk di dalam pemberitaan Gereja ialah apa yang tiap hari Minggu berlaku dalam kebaktian. ${ }^{2}$ Sekolah minggu merupakan kegiatan bersekolah yang diadakan pada hari Minggu. Banayak denominasi Kristen yang mengajarkan pelajaran kegamaan di dalam sekolah minggu. Biasanya kegiatan Sekolah Minggu diadakan dalam sebuah gereja. Guru atau pembimbing biasanya terdiri dari orang-orang Kristen awam.

\footnotetext{
${ }^{1}$ Khotbah Eksposisi Narasi Yang Kreatif dan Kontekstual Bagi Anak-anak Generasi Z Usia 5-6 Tahun(http://jurnal.stt-gamaliel.ac.id/index.php/gamaliel/articel/view/41/11)

2 Boland, BJ., Van Niftrik, Dogmatika Masa Kini (Jakarta: BPK. Gunung Mulia, 2015),hal.16-17
} 
Pendidikan merupakan hal yang tidak dapat dipisahkan dari kehidupan manusia yang selalu ingin berkembang dan berubah. Guru atau pembimbing memiliki peranan yang sangat penting dalam menentukan kualitas dan kuantitas pengajaran yang dilaksanakannya. Oleh sebab itu, guru atau pembimbing harus memikirkan dan membuat perencanaan secara seksama dalam meningkatkan kesempatan belajar bagi anak SGM yang dididik dan dibinannya untuk memperbaiki kualitas anak dalam menerima cerita atau khotbah dengan baik. Dalam artian bagaimana kita sebagai guru atau pembimbing untuk membina anak SGM dengan baik dan benar sesuai dengan pedoman yang ada.

Dewasa ini, sering kita melihat kualitas pendidikan di Indonesia mengalami degradasi dari masa kemasa, dan ini juga berdampak dalam Sekolah Minggu. ${ }^{3}$ Untuk itu pembinaan SGM melalui cerita yang kreatif sangatlah penting bagi anak SGM agar mudah dimengerti dan dipahami oleh anak-anak SGM. Dengan adanya cerita yang kreatif dan kontekstual dapat meningkatkan kepuasan anak SGM untuk mengikuti ibadah hari minggu.

\section{Tujuan}

Untuk mengetahui Implementasi Cerita Kreatif dan Kontekstual untuk Meningkatkan Aktivitas Belajar Anak SGM di Gereja Toraja

\section{Manfaat}

Memberikan sumbangan pengetahuan dalam bidang pelayanan gereja bagi mahasiswa.

\section{E. Pembahasan}

PAIKEM merupakan model pembelajaran di mana PAIKEM menjadi pedoman dalam bertindak untuk mencapai tujuan yang telah ditetapkan. Dengan pelaksanaan pembelajaran PAIKEM, di harapkan berkembang berbagai macam motivasi kegiatan pembelajaran untuk mencapai tujuan pembelajaran yang partisipatif, aktif, kreatif, efektif, dan menyenangkan. Pembelajaran merupakan implementasi kurikulum di sekolah dari kurikulum yang sudah dirancang dan menuntut aktivitas dan kreativitas guru dan siswa sesuai dengan rencana yang telah diprogramkan secara efektif dan menyenangkan. Oleh karena itu, guru harus mampu menciptakan suasana pembelajaran partisifatif, aktif, kreatif, efektif, dan menyenangkan supaya kompetensi dasar dan standar kompetensi yang telah dirancang dapat tercapai.

\footnotetext{
${ }^{3}$ http://www.kompasiana.com/www.bohari.com/kondisi-pendidikan-diindonesia-dan-penyebabtidak-efektifnya-hasil-belajar (diakses pada tanggal 17 Maret 2020)
} 
Guru harus menyadari bahwa pembelajaran memiliki sifat yang sangat kompleks. Ada yang bisa menguasai materi lebih cepat dengan keterampilan motorik (kinestetik), ada yang menguasai materi lebih cepat dengan melihat atau membaca (visual). Dalam metode PAIKEM ini, guru dituntut untuk dapat melakukan kegiatan pembelajaran yang dapat melibatkan siswa melalui partisipatif, aktif, kreatif, efektif, dan menyenangkan yang pada akhirnya siswa dapat menciptakan sebuah karya, gagasan, pendapat, ide atas hasil penemuannya dan usahanya sendiri, bukan dari gurunya.

> Pembelajaran partisipatif adalah pembelajaran yang melibatkan siswa dalam kegiatan pembelajaran secara optimal. Jadi pembelajaran akan lebih bermakna bila siswa diberikan kesempatan untuk berpartisipasi dalam berbagai aktivitas kegaiatan pembelajaran, sementara guru berperan sebagai fasilitator dan mediator sehingga siswa mampu berperan dan berpartisipasi aktif dalam mengaktualisasikan kemampuannya di dalam dan di luar kelas. Pembelajaran aktif merupakan pendekatan pembelajaran yang lebih banyak melibatkan aktivitas siswa dalam mengakses berbagai informasi dan pengetahuan untuk dibahas dan dikaji dalam proses pembelajaran di kelas sehingga mereka mendapatkan berbagai pengalaman yang dapat meningkatkan pemahaman dan kompetensinya. Dalam pembalajaran aktif, guru lebih banyak memosisikan dirinya sebagai fasilitas yang bertugas memberikan kemudahan belajar (to facilitate of learning) kepada siswa. Siswa terlibat secara aktif dan berperan dalam proses pembelajaran, sedangkan guru lebih banyak memberikan arahan dan bimbingan, serta mengatur sirkulasi dan jalannya proses pembelajaran. Pembelajaran kreatif merupakan proses pembelajaran yang mengharuskan guru untuk dapat memotivasi dan memunculkan kreativitas siswa selama pembelajaran berlangsung, dengan menggunakan beberapa metode dan strategi yang bervariasi, misalnya kerja kelompok, bermain peran, dan pemecahan masalah. pembelajaran kreatif menuntut guru untuk merangsang kreativitas siswa, baik dalam mengembangkan kecakapan berpikir maupun dalam melakukan suatu tindakan. Pembelajaran dapat dikatakan efektif jika mampu memberikan pengalaman baru dan membentuk kompetensi siswa serta mengantarkan mereka ketujuan yang ingin dicapai secara optimal. Pembelajaran efektif menuntut keterlibatan siswa secara aktif karena mereka merupakan pusat kegiatan pembelajaran dan pembentukan komptensi. Pembelajaran efektif perlu didukung oleh suasana dan lingkungan belajar yang memadai/kondusif. Oleh karena itu, guru 
harus mampu mengelola siswa, mengelola kegiatan pembelajaran, mengelola isi/materi pembelajaran, dan mengelola sumber-sumber belajar. Menciptakan kelas yang efektif dengan peningkatan efektivitas proses pembelajaran tidak bisa dilakukan secara persial, melainkan harus menyeluruh mulai dari perencanaan, pelaksanaan, dan evaluasi. Pembelajaran menyenangkan (joyfull instruction) merupakan suatu proses pembelajaran yang didalamnya terdapat suatu kohesi yang kuat antara guru dan siswa, tanpa ada peranan terpaksa atau tertekan (not under pressure). Bisa juga disebut, pembelajaran menyenangkan adalah adanya pola hubungan yang baik antara guru dengan siswa dalam proses pembelajaran. Untuk mewujudkan proses pembelajaran yang menyenangkan, guru harus mampu merancang pembelajaran dengan baik, memilih materi yang tepat, serta memilih dan mengembangkan strategi yang dapat melibatkan siswa secara optimal.

Model PAIKEM ini diharapkan dapat menghasilkan pembelajaran yang berkualitas/bermutu dan menghasilkan perubahan yang signifikan, seperti dalam peran guru di kelas, perlakuan terhadap siswa, pertanyaan, latihan, interaksi dan pengelolaan kelas.

Model-model Pembelajaran yang Mendukung Pembelajaran PAIKEM

Dalam perkembangan model-model pembelajaran, ternyata terdapat beberapa model pembelajaran yang sebenarnya telah memuat konsep PAIKEM. Menurut Udin S.Saud terdapat tiga model tersebut pada dasarnya mendukung PAIKEM, yaitu: Pembelajaran Kuantum (Quantum Teaching), Pembelajaran kuantum ini merupakan bentuk inovasi dari penggubahan bermacam-macam interaksi yang ada di dalam dan di sekitar momen belajar. Pengubahan hambatan-hambatan belajar tersebut bisa dengan menggunakan beberapa cara, yaitu dengan mulai membiasakan menggunakan lingkungan sekitar belajar sebagai media belajar, menjadikan sistem komunikasi sebagai perantara ilmu dari guru ke siswa yang paling efektif, dan memudahkan segala hal yang diperlukan oleh siswa. Dengan prinsip-prinsip seperti itu, maka mekanisme pembelajaran partisipatif aktif, kreatif, efektif dan menyenangkan akan bisa dicapai baik oleh siswa atau oleh guru. Dalam pembelajaran kuantum, terdapat kerangka-kerangka yang menjamin siswa menjadi tertarik dan berminat pada setiap masa pelajaran. Oleh karena itu, dalam pembelajaran kuantum ini terdapat tujuan yang kemudian menjadi tujuan pokok dalam suatu proses pembelajaran untuk siswa, yaitu meningkatkan partisipasi siswa, meningkatkan motivasi dan minat belajar, meningkatkan daya ingat, 
meningkatkan rasa kebersamaan, meningkatkan daya dengar, dan meningkatkan kehalusan perilaku. Dalam pembelajaran berbasis kompetensi ini, aspek-aspek yang ditingkatkan lebih kepada kemampuan dasar siswa pada tahap pengetahuan, keterampilan, dan bersikap. Pembelajaran kontekstual atau yang lebih dikenal dengan sebutan CTL (contextual teaching and learning) merupakan konsep belajar yang beranggapan bahwa anak akan belajar lebih baik jika lingkungan diciptakan secara almiah. Dari pengertian di atas bisa dipahami bahwa CTL adalah konsep belajar yang membantu guru menghubungkan antara materi pelajaran yang akan diajarkannya kepada siswa sesuai dengan kondisi yang terjadi dan mendorong siswa untuk bisa menerapkan pengetahuan yang didapat dalam kehidupan seharihari. Dalam pelaksanaannya CTL dipengaruhi oleh berbagai faktor yang datang baik dari dalam ataupun dari luar. Berdasarkan faktor-faktor di atas, dapat disimpulkan bahwa cakupan untuk pembelajaran kontekstual ini adalah penekanan pada hal-hal yang bersifat makna dari materi yang telah diajarkan oleh guru dan perhatian terhadap faktor kebutuhan individu siswa.

Pembelajaran Tematik, penerapan pembelajaran tematik di sekolah dasar tingkat rendah sangat mendukung penerapan model pembelajaran PAIKEM. Model tematik ini tepat karena suatu pendekatan yang menghubungkan berbagai mata pelajaran yang mencerminkan dunia riil di sekeliling perkembangan anak. Pembelajaran tenatik adalah pembelajaran terpadu yang menggunakan tema sebagai pemersatu materi dalam beberapa mata pelajaran sekaligus dalam satu kali tatap muka. Jadi, pembelajaran tematik merupakan strategi untuk mengenalkan berbagai konsep kepada anak didik secara utuh dengan menggunakan tema agar konsep yang dipelajari itu bisa dipahami dengan mudah dan jelas. Pembelajaran ini merupakan pembelajaran yang melibatkan beberapa mata pelajaran untuk memberikan pengalaman yang bermakna bagi siswa.

\section{Pemaparan Hasil Penelitian di salah satu Gereja Toraja}

A. Minggu, 08 Maret 2020

Pada minggu ketiga di bulan Februari, saya melakukan penelitian terhadap anak sekolah minggu (Anak Kecil) di Gereja Toraja Jemaat X. Dengan menggunakan metode pembelajaran PAIKEM saya berharap anak-anak dapat aktif, inovatif, kreatif dan menyenangkan dalam proses belajar di dalam ruangan. Untuk memulai aktifitas dalam ruangan, saya memulainya dengan memeberi salam, menyapa atau menanyakan kabar mereka pada hari itu. Mereka begitu antusias 
menjawab pertanyaan yang saya berikan, kemudian saya membuka ibadah dengan mengangkat satu lagu yang membutuhkan gerak tubuh (lagu dan gerak). Dengan memberikan lagu-lagu yang semangat dapat membuat anak aktif dalam melakukan kegiatan.

Untuk masuk dalam votum dan salam saya sedikit bercerita kepada mereka bahwa Tuhan Yesus begitu baik sehingga Ia masih memberikan kita oksigen, kesehatan dan kekuatan sehingga kita masih dapat beraktifitas di pagi ini. Ketika mereka sadar akan kebaikan Tuhan saya mengajak mereka untuk berdoa (masuk dalam Votum dan Salam), setelah itu saya kembali mengajak mereka bernyanyi karena dengan menyanyi anak dapat mengekspresikan dirinya. Setelah bernyanyi saya kembali mengajak mereka bercerita tentang hal-hal apa saja yang mereka lakukan sebelum ke Gereja atau aktifitas mereka kemarin, mereka dengan aktif menjawab setiap pertanyaan yang saya berikan. Mereka sangat aktif menjawab karena pertanyaan yang saya berikan adalah kisah yang mereka lalui sendiri, mereka menjawab sesuai apa sudah mereka alami entah itu pengalaman baik ataupun buruk. Untuk itu saya mengajak mereka tunduk di hadapan Tuhan untuk mengaku segala kesalahan yang telah diperbuat dengan bentuk lagu "Tuhan kami berlumuran dosa". Dengan mengajak anak dari dini untuk mengakui kesalahan yang telah mereka buat, sekecil apaun kesalahan itu ketika mereka berani mengakuinya salah satu contoh keberanian yang luar biasa dan akan tertanam dalam benak mereka bahwa mereka harus mengakui setiap kesalahan atau pelanggaran yang ia perbuat agar anak dapat bertanggung jawab atas kesalahan yang ia lakukan. Ketika kami selesai mengakui kesalahan kami di hadapan Tuhan, saya kembali mengajak mereka untuk bernyanyi. Karena kami telah mengakui segala kesalahan kami, saya memperdengarkan kepada mereka berita anugerah dari Tuhan. Dengan begitu anak merasa bahwa ketika mereka telah mengakui kesalahan mereka dihadapan Tuhan, Tuhan tetap mengasihi dan menyayangi mereka dengan memberikan kabar bahagia. Setelah memperdengarkan kepada mereka berita anugerah, kembali saya mengajak mereka untuk memberikan tanda ucapan syukur entah berupa uang ataupun hati yang tulus datang kepada Tuhan. Dengan begitu anak-anak yang tidak membawa persembahan mereka tetap antusias memberi diri untuk selalu dekat kepada Tuhan dengan cara rajin ke sekolah minggu.

Ketika saya membawa pundi persembahan, anak-anak begitu bersemangat sehingga ada yang memberi diri untuk membawa pundi dan menjalankannya 
kesetiap bangku-bangku. Selepas siapa saya dan apa yang saya lakukan saat berdiri dihadapan mereka, dengan melihat mereka aktif saya merasakan kebahagiaan tersendiri bahwa anak-anak begitu semangat dalam memuliakan Tuhan. Setelah mereka memberi tanda ucapan syukur mereka, saya memberi kesempatan kepada mereka yang siap mendoakan persembahan yang telah kami masukkan. Saya berfikir bahwa pasti dari mereka tidak ada yang siap, namun hal yang mengejutkan bagi saya bahwa diantara mereka ada yang mengajukan diri untuk berdoa dengan begitu saya mempersilahkan anak tersebut mendoakan persembahan kami.

Seusai mendoakan persembahan, saya kembali mengajak adik-adik saya untuk memuji Tuhan. Setelah itu kami bercerita sedikit tentang hal-hal sekaitan dengan tema cerita kami waktu itu, sebelum itu kami masuk dalam doa pembacaan Alkitab agar Tuhan menuntun kami dalam memahami dan merenungkna firmanNya dengan baik. AMIN... untuk mengakhiri permohonan kami pada Tuhan, sebelum masuk dalam cerita kami sedikit membahas tentang keseharian adik-adik sekolah minggu, ketika mereka disekolah, dirumah dan di tempat bermain. Ketika saya bertanya kepada mereka, bagaiamana perasaan mereka saat mereka masih diberikan kesehatan, kekuatan oleh Tuhan? Mereka menjawab, sangat senang, bahagia, berterima kasih kepada Tuhan karena Tuhan masih sayang kepada saya dan keluarga. Mereka menjawab penuh dengan rasa sukacita yang luar biasa, setalah itu kami masuk dalam cerita. Saya bercerita dengan cara menjelaskan dan juga dengan bentuk nyanyian agar mereka tidak bosan dalam mendengar cerita. Kemudian saya memberikan sedikit gambar untuk menambah warna dalam cerita anak, dengan menggunakan gambar-gambar tersebut anak tertarik untuk memperhatikan alur cerita yang saya sampaikan. Anak akan senang jika memakai alat peraga semacam gambar ataupun yang lainnya. Dengan begitu anak mudah menyerap apa yang kita sampaikan kepada mereka.

Ketika cerita selesai, kami membaca Alkitab yang sekaitan dengan cerita yang saya sampaikan kami melanjutkan dengan menyanyi dan berdoa syafaat. Sebelum saya berdoa, saya menanyakan kepada adik-adik bahwa adakah diantara mereka yang ingin di doakan entah itu saudara, orang tua ataupun diri sendiri. Dengan begitu anak-anak bisa menyebutkan siapa saja yang ingin mereka doakan. Kami masuk dalam doa syafaat. 


\section{F. Kesimpulan dan Saran}

Model dan metode ini dapat diaplikasikan oleh guru-guru Sekolah Minggu Gereja Toraja dan dapat menjawab semua kebutuhan Anak Sekolah Minggu. Dengan ini dapat menghasilkan generasi-generasi Anak Sekolah Minggu yang sigap dalam menangkap cerita yang disampaikan oleh pembimbing atau guru $\mathrm{SGM}^{4}$

Sarannya agar anak lebih mengerti dan memahami cerita atau khotbah yang disampaikan oleh guru atau pembimbing SGM diharapkan agar memiliki banyak metode atau model yang lebih kreatif lagi agar anak tidak bosan dalam mendengarkan Firman Tuhan yang disampaikan.

${ }^{4}$ Model Ibadah Sekolah Mingggu Kreatif-Interaktif bagi Generasi Alfa di Gereja Toraja (http://www.jurnalbia.com/index.php/bia/article/view/127/pdf ) 